\title{
Spoilage potential and sensory profile associated with bacteria isolated from cold-smoked salmon
}

\author{
V. Stohr, J. J. Joffraud *, M. Cardinal and F. Leroi
}

IFREMER, Centre de Nantes, Laboratoire de Génie Alimentaire, Nantes, BP 21105, 44311 Nantes Cedex 03, France

*: joffraud@ifremer.fr

\begin{abstract}
Off-odours/flavours associated with cold-smoked salmon spoilage are due to the activity of microflora. This study evaluated the spoilage potential of nine bacterial groups (Shewanella putrefaciens, Brochothrix thermosphacta, Aeromonas spp., Lactobacillus alimentarius, Lactobacillus sake,Lactobacillus farciminis, Carnobacterium piscicola, Photobacterium phosphoreum and Serratia liquefaciens) isolated from cold-smoked salmon. Five different isolates from each group were inoculated into sterile cold-smoked salmon blocks, and chemical and sensory changes were studied after five weeks of storage in vacuum packs at $6^{\circ} \mathrm{C}$. Bacterial growth was monitored weekly during the storage period. A sensory profile was assigned to each group. Principal component analysis allowed some bacterial species to be characterised by a specific odour, and correspondence factorial analysis discriminated among the species according to their spoilage potential. The bacteria mainly responsible for spoilage were L. sake, L. farciminis and B. thermosphacta, which produced sulphurous, acidic and rancid off-odours respectively. Some strains of $\mathrm{S}$. liquefaciens produced rubbery, cheesy or acidic offodours. Some P. phosphoreum isolates were characterised by an acidic effect.
\end{abstract}

Keywords: Cold-smoked salmon; Bacteria; Spoilage potential; Sensory analysis 


\section{INTRODUCTION}

Cold-smoked salmon currently produced by a light salting and smoking process is highly perishable and has limited shelf-life. Sensory modifications occur early during vacuum storage at chilled temperature, and the spoiled product is characterised by off-odours and pasty texture (Truelstrup Hansen et al., 1996; Paludan-Müller et al., 1998). The main defects are due to microbial activity. Although several studies have identified the microflora of coldsmoked fish (Civera et al., 1995; Leroi et al., 1998; Truelstrup Hansen et al., 1998; Lyhs et al., 1998), the spoilage mechanisms are poorly understood. No correlation appears to exist between total bacterial levels and spoilage as only some species participate in the process (Gram \& Huss, 1996; Leroi et al., 1998). The total bacterial count at the sensory rejection point is generally around $10^{7}-10^{8} \mathrm{cfu} \mathrm{g}^{-1}$, although the microflora isolated differs considerably from one study to another, depending on the processes involved in different plants and the microbiological methods used for analysis (Truelstrup Hansen et al., 1998). Nonetheless, lactic acid bacteria (LAB) are generally predominant in spoiled cold-smoked salmon flora, and different Gram-negative bacteria are often present. The off-odours and flavours that develop in vacuum-packed cold-smoked salmon have previously been described as sour, acid, pungent and occasionally faecal (Truelstrup Hansen, 1995; Leroi et al., 1998). However, no clear link has yet been established between spoilage characteristics and specific microbial species.

The present study used sensory analysis to investigate the off-odours produced by bacteria belonging to nine different taxonomic groups previously isolated from cold-smoked salmon (Leroi et al., 1998). Each group was represented by five strains. The species responsible for spoilage were identified and then correlated with the development of specific off-odours. 


\section{MATERIALS AND METHODS}

\section{Smoked salmon and bacterial strains}

Sterile smoked salmon blocks were prepared as described by Joffraud et al. (1998). Ten fresh salmon (Salmo salar, Norway) were purchased on the market (Nantes, France), filleted, salted, dried and smoked at IFREMER. Smoked fillets were cut in small blocks of 1 to $2 \mathrm{~g}$ each in very strict hygienic processing conditions. Samples were covered with aluminium foil, vacuum-packed in different sterile bags (360 grams each) and frozen at $-80^{\circ} \mathrm{C}$. The frozen vacuum packs were sterilised by ionising treatment at $1.5 \mathrm{kGy}$ (SPI, Berric, France). Bags were stored frozen until inoculation.

All bacterial strains belonged to the IFREMER collection and were previously isolated and identified from vacuum-packed cold-smoked salmon at different time intervals during chilled storage (Leroi et al., 1998). Strains were maintained as frozen stocks at $-80^{\circ} \mathrm{C}$ in the presence of 50\% glycerol. The different strains and corresponding labels used in graphs are shown in Table 1.

Table 1. Species of strains used for cold-smoked salmon inoculation and corresponding labels mentioned in figures 2 and 3B. Five strains per group were inoculated, and eight control samples (one per sensory session) were used.

\begin{tabular}{lc}
\hline Species & Labels \\
\hline Shewanella putrefaciens & $\mathrm{S} 1, \mathrm{~S} 2, \mathrm{~S} 3, \mathrm{~S} 4, \mathrm{~S} 5$ \\
Photobacterium phosphoreum & $\mathrm{P} 1, \mathrm{P} 2, \mathrm{P} 3, \mathrm{P} 4, \mathrm{P} 5$ \\
Serratia liquefaciens & $\mathrm{E} 1, \mathrm{E} 2, \mathrm{E} 3, \mathrm{E} 4, \mathrm{E} 5$ \\
Aeromonas spp. & $\mathrm{A} 1, \mathrm{~A} 2, \mathrm{~A} 3, \mathrm{~A} 4, \mathrm{~A} 5$ \\
Brochothrix thermosphacta & $\mathrm{B} 1, \mathrm{~B} 2, \mathrm{~B} 3, \mathrm{~B} 4, \mathrm{~B} 5$ \\
Carnobacterium piscicola & $\mathrm{C} 1, \mathrm{C} 2, \mathrm{C} 3, \mathrm{C} 4, \mathrm{C} 5$ \\
Lactobacillus alimentarius & LA1, LA2, LA3, LA4, LA5 \\
Lactobacillus farciminis & LF1, LF2, LF3, LF4, LF5 \\
Lactobacillus sake & LS1, LS2, LS3, LS4, LS5 \\
\hline Control samples & $\mathrm{T} 1, \mathrm{~T} 2, \mathrm{~T} 3, \mathrm{~T} 4, \mathrm{~T} 5, \mathrm{~T} 6, \mathrm{~T} 7, \mathrm{~T} 8$ \\
\hline
\end{tabular}




\section{Sample inoculation and packaging}

Bacterial strains were revived from frozen storage and pre-cultured for 2 days at $20^{\circ} \mathrm{C}$ in brain heart infusion broth (Biokar, Beauvais, France), with the exception of Carnobacterium piscicola and Lactobacillus spp., which were cultured in Elliker broth (Biokar) and in Man Rogosa and Sharp broth (MRS, Biokar), respectively. The cultures were then diluted 100-fold in cooled physiological water $(0.85 \% \mathrm{NaCl}$ and $0.1 \%$ peptone) in order to inoculate the product at levels of $10^{4}-10^{5} \mathrm{cfu} \mathrm{g}^{-1}$. For each strain, one bag (360 g) of sterile cold-smoked salmon blocks was surface-inoculated by addition of $7.2 \mathrm{ml}$ of the diluted culture, followed by careful mixing of the bag contents. Blocks were then allotted and vacuum-packed in 17 different polyamide/polyethylene bags (PA/PE 20/70, Euralpac, Alfo, Germany). Permeability was $40-50 \mathrm{~cm}^{3} / \mathrm{m}^{2}$ for $\mathrm{O}_{2}$ and $146 \mathrm{~cm}^{3} / \mathrm{m}^{2}$ for $\mathrm{CO}_{2}$ at $24 \mathrm{~h}\left(1 \mathrm{~atm}\right.$ at $23^{\circ} \mathrm{C}, 75 \%$ r.F). Bag weight differed depending on the type of analysis (15 $\mathrm{g}$ for microbial analysis and $20 \mathrm{~g}$ for sensory and chemical analysis). French regulations prescribe a storage temperature range of $0-4^{\circ} \mathrm{C}$ for chilled smoked salmon (NF V 45-065, 1997), but $6^{\circ} \mathrm{C}$ was chosen to mimic temperature abuse at different stages from production to consumption (transport, commercial and domestic refrigeration, etc.). Immediately after inoculation and then every week until week 5, one bag from each treatment (i.e. each bacterial strain) was opened for microbiological analysis. The remaining bags were stored for 5 weeks and then used for sensory and chemical analysis. A control treatment involved inoculation with $7.2 \mathrm{ml}$ of sterile physiological water into sterile cold-smoked salmon blocks. 


\section{Quantitative microbiological analysis}

Each week, bacterial strains were counted by a direct plating technique. Flesh samples (15 g) were homogenised with $60 \mathrm{ml}$ of chilled physiological water in a filter stomacher bag for 2 min in a stomacher 400 (Lab Blender, London, UK) and left at room temperature for 30 min for resuscitation. The homogenates were serially diluted ten-fold in physiological water, and $0.1 \mathrm{ml}$ of each appropriate dilution was spread on duplicate plates. The numbers of Shewanella putrefaciens, Brochothrix thermosphacta, Aeromonas spp, and Serratia liquefaciens were determined on plate count agar (Biokar). Plates were incubated aerobically for three days at $20^{\circ} \mathrm{C}$. Photobacterium phosphoreum was enumerated after five days of aerobic incubation at $15^{\circ} \mathrm{C}$ on Long and Hammer medium with $1 \% \mathrm{NaCl}$, as described by Van Spreekens (1974). Lactobacillus spp were plated on MRS agar (Biokar), and C. piscicola on Elliker broth with 1.5\% of agar. MRS and Elliker plates were both placed in anaerobic jars $\left(20 \% \mathrm{CO}_{2}, 80 \% \mathrm{~N}_{2}\right.$ ) with Anaerocult A (Merck, Darmstadt, Germany) at $20^{\circ} \mathrm{C}$ for five days.

\section{Chemical analysis}

After five weeks of storage, total volatile base nitrogen (TVBN) and trimethylamine (TMA) were determined in duplicate by the Conway micro-diffusion method (Conway \& Byrne, 1933). pH was measured directly in the flesh with a Mettler Delta 320 pH-meter (AES, Combourg, France). Measurements were performed both on reference and assay samples. 


\section{Sensory analysis}

Twelve trained panellists were asked to characterise the influence of each strain on coldsmoked salmon odours and spoilage. Ten training sessions involving odour recognition and profiling tests were carried out. Initially, recognition tests were performed by means of aromatic molecules in a water solution or added to cold-smoked salmon blocks. These molecules had been identified as related to odours of spoiled cold-smoked salmon (Joffraud et al., in press). Aromatic references and spoiled smoked salmon samples were presented to the panel during two discussion sessions to check on their understanding of the criteria used and determine the final descriptors. The 14 attributes selected (Table 2) as good spoilage indicators were then used to profile the cold-smoked salmon samples obtained from the supermarket and stored until spoilage. After this final training period, the panellists were asked to perform a profiling test, requiring 8 sessions to examine 45 samples (9 bacterial groups x 5 strains per group). During each session, 6 inoculated samples and one control were presented in randomised order to the panellists, who judged the odour attributes using a nonstructured 80-mm line scale, anchored at each end. At the end of the profiling test, panellists classified each sample according to the spoilage level (NS: non-spoiled; LS: lightly spoiled; SS: strongly spoiled). 
Table 2. List of sensory spoilage descriptors used for cold-smoked salmon and corresponding codes mentioned in figure $3 \mathrm{~A}$.

\begin{tabular}{lc}
\hline Sensory descriptors & Codes used for statistical analysis \\
\hline amine/urine & amin \\
acid/vinegar & acid \\
green aroma/freshly cut grass & grass \\
rancid/linseed oil & rancid \\
ham/cooked meat & ham \\
plastic/citrus fruit & plast \\
sour/fermented & sour \\
butter/caramel & butter \\
rubber & rubber \\
cheese/feet & cheese \\
blue cheese/musty & musty \\
hydrogen sulfide/egg & $\mathrm{H}_{2} \mathrm{~S}$ \\
cabbage/gas/garlic & cabb \\
faecal & faec \\
\hline
\end{tabular}

\section{Statistical methods}

Chemical data were studied by analysis of variance using statistical software (Statgraphics Plus, version 3, Sigma Plus, Paris, France), and means were compared by the least significance difference test at the 0.05 level of probability to determine similarities in biochemical activity between and/or within bacterial groups.

The sensory classification into 3 spoilage levels allowed correspondence factorial analysis (CFA) on Uniwin software (Uniwin Plus, version 3, Sigma Plus). The link between the qualitative variables (isolates and spoilage levels) were plotted according to two factorial axes, thereby representing three spoilage levels. One of the two axes was expected to accumulate enough information from original data to represent a "spoilage axis" from NS to SS level. This method allowed the bacterial isolates to be discriminated according to their spoilage potential. 
The results of the profiling tests were modified to compensate for variations among assessors in their scoring range. Sensory data were standardised using an isotropic scaling factor according to the procedure proposed by Kunert \& Quannari (1999). These data were represented as a matrix of 53 lines (45 assays plus 8 controls) and 14 columns corresponding to the 14 descriptors noted. Principal component analysis (PCA), using the same Uniwin software as for CFA, uses the original data to construct linear combinations (components) with maximal variance. PCA was used to reduce the number of variables represented by the 14 descriptors to a smaller number of components, without loss of essential information. The first component accounts for the largest portion of variance, the second for the second largest portion, and so on until all the variance has been accounted for. In practice, the investigator determines the number of components formed. In other words, this method allows the data to be summarised in a few dimensions (components), while still accounting for differences or similarities between the samples described by the data. In this study, the number of new dimensions (components) was limited to two. This analysis allowed the attribution of typical sensory descriptors to each isolate and an estimation of the similarity of the spoilage characteristics of the strains.

\section{RESULTS}

\section{Microbiological results}

Figures $1 \mathrm{~A}$ and $1 \mathrm{~B}$ show the mean growth patterns of the different groups of bacteria during vacuum storage at $6^{\circ} \mathrm{C}$. All bacterial species grew well on sterile cold-smoked salmon blocks. Except for Sh. putrefaciens and P. phosphoreum, all groups reached their maximum levels after two or three weeks of storage, with final counts ranging between $5 \times 10^{7}$ and $10^{9} \mathrm{cfu} \mathrm{g}^{-1}$. The numbers of Sh. putrefaciens increased slowly, and two of the five strains remained within 
one $\log _{10}\left(\mathrm{cfu} \mathrm{g}^{-1}\right)$ of the initial inoculation level at the end of storage. For the other strains, the difference reached 3-4 $\log _{10}\left(\mathrm{cfu} \mathrm{g}^{-1}\right)$ (data not shown). P. phosphoreum strains increased rapidly during the first week (to approximately $5 \times 10^{7} \mathrm{cfu} \mathrm{g}^{-1}$ ) and then decreased slowly to levels between $10^{6}$ and $10^{7} \mathrm{cfu} \mathrm{g}^{-1}$.

Figure 1. Development of bacterial groups in cold-smoked salmon during vacuum storage at $6^{\circ} \mathrm{C}$ : (A) Gramnegative and (B) Gram-positive bacteria. Each growth curve represents the mean of 5 strains from each bacterial group.
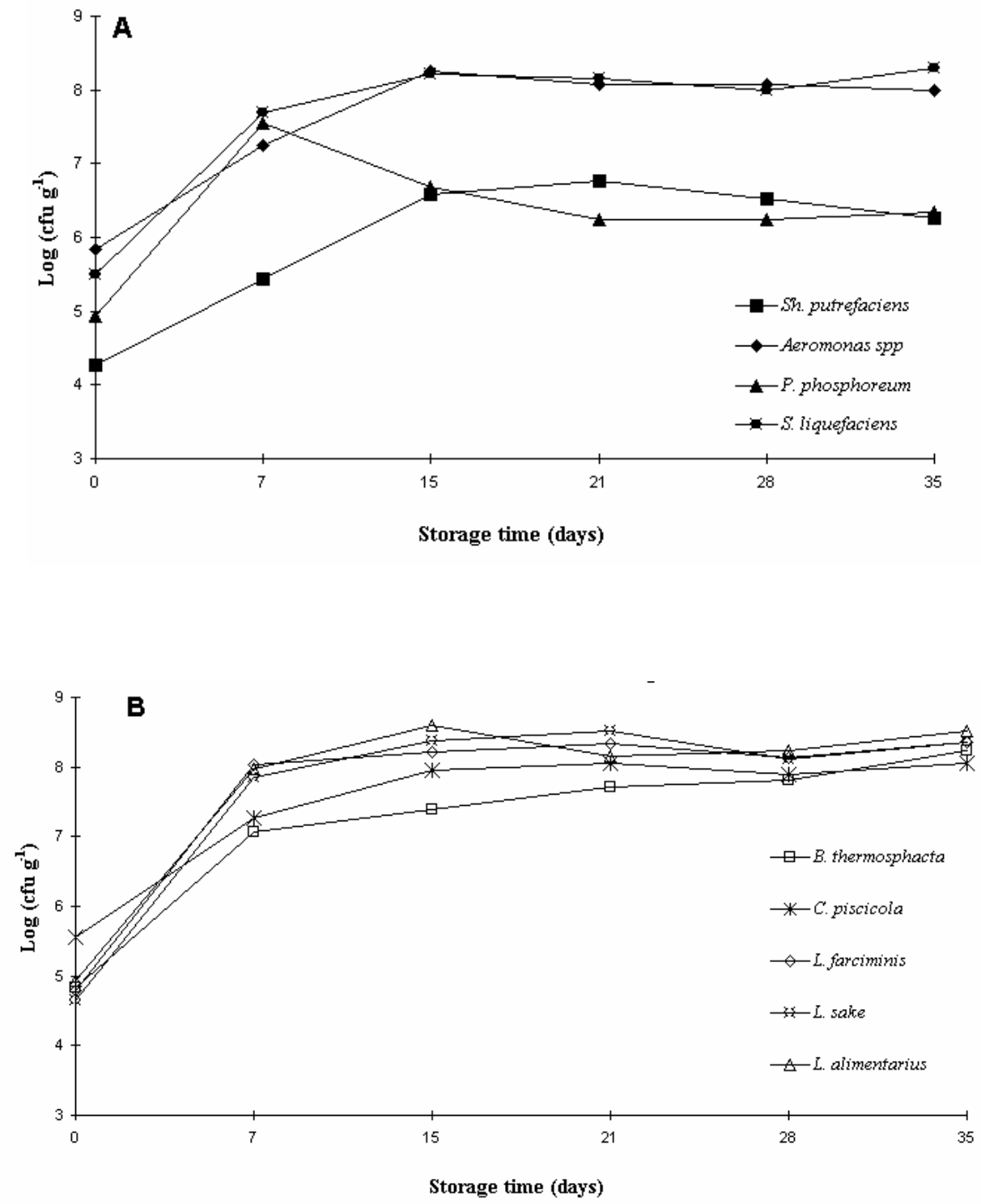


\section{Chemical results}

Mean values of $\mathrm{pH}$, TMA and TVBN production have been calculated from the 5 strains belonging to each species. (Table 3).

Table 3. Mean values ( $\mathrm{n}=5$ strains per species) of $\mathrm{pH}$, TMA and TVBN after 5 weeks of vacuum storage at $6^{\circ} \mathrm{C}$.

\begin{tabular}{|c|c|c|c|c|c|c|}
\hline \multirow[b]{2}{*}{ Bacterial species } & \multicolumn{2}{|c|}{ pH } & \multicolumn{2}{|c|}{ TMA (mg-N $\left.100 \mathrm{~g}^{-1}\right)$} & \multicolumn{2}{|c|}{ TVBN (mg-N $100 \mathrm{~g}^{-1}$ ) } \\
\hline & mean (a) & LSD (b) & mean (a) & LSD (b) & mean (a) & LSD (b) \\
\hline Aeromonas spp & $6.25(0.05)$ & cde (4) & $13.1(0.4)$ & $\mathrm{d}(3)$ & $37.7(4.5)$ & $f(3)$ \\
\hline B. thermosphacta & $5.98(0.04)$ & $\mathrm{b}(2)$ & $2.4(0.5)$ & a (1) & $20.8(4.4)$ & a (1) \\
\hline C. piscicola & $5.95(0.05)$ & $\mathrm{b}(2)$ & $5.6(1.3)$ & $\mathrm{b}(2)$ & $26.2(3.1)$ & bc (2) \\
\hline Lb. alimentarius & $5.65(0.11)$ & a (1) & $3.0(0.5)$ & a (1) & $23.1(0.9)$ & $\mathrm{ab}(1)$ \\
\hline Lb. farciminis & $5.69(0.08)$ & a (1) & $3.7(1.2)$ & a (1) & 33.9 (6.3) & ef (3) \\
\hline Lb. sake & $5.71(0.07)$ & a (1) & $2.8(0.7)$ & a (1) & 33.4 (3.8) & ef (3) \\
\hline P. phosphoreum & $6.17(0.07)$ & c (4) & $12.0(0.6)$ & cd (3) & $32.4(1.6)$ & de (3) \\
\hline Sh. putrefaciens & $6.28(0.05)$ & e (3) & $11.0(2.0)$ & c (3) & $28.2(2.8)$ & cd (2) \\
\hline S. liquefaciens & $6.26(0.08)$ & de (4) & $12.4(1.2)$ & d (3) & $35.0(2.4)$ & ef (3) \\
\hline Control assay & $6.18(0.03)$ & cd (4) & $2.7(0.8)$ & a (1) & $19.4(1.6)$ & a (1) \\
\hline
\end{tabular}

(a) standard error (SE) ; (b) Group number

Fresh cold-smoked salmon had a mildly acidic pH of $6.18 \pm 0.03$ (SE) Spoilage of the product significantly increased or decreased $\mathrm{pH}$, depending on the bacterial species. Three trends were distinguished: acidified products (all Lactobacillus species, $\mathrm{pH}$ ranging from 5.65 to 5.70), products with moderate acidification (C. piscicola and B. thermosphacta, pH 5.95 to 6.00), and products with slightly increased $\mathrm{pH}$ (Sh. putrefaciens, $\mathrm{pH}=6.28)$. For the other strains (S. liquefaciens, Aeromonas spp and P. phosphoreum), there was no significant modification in $\mathrm{pH}$.

TMA production was not high for any of the species. The TMA concentration increased from $2.7 \pm 0.8(\mathrm{SE}) \mathrm{mg}-\mathrm{N} 100 \mathrm{~g}^{-1}$ in the control to a maximum of $13.1 \mathrm{mg}-\mathrm{N} 100 \mathrm{~g}^{-1}$, depending on the bacterial type. Lactobacillus species and B. thermosphacta did not produce TMA, C. piscicola produced small amounts of TMA (5.6 mg-N $100 \mathrm{~g}^{-1}$ ), whereas the Gramnegative strains produced concentrations ranging from 11.0 to $13.1 \mathrm{mg}-\mathrm{N} 100 \mathrm{~g}^{-1}$. 
Variable production of TVBN was observed for all bacterial groups. The initial TVBN content of cold-smoked salmon was $19.4 \pm 1.6 \mathrm{mg}-\mathrm{N} 100 \mathrm{~g}^{-1}$ (SE). Statistical analysis showed three patterns: nearly no TVBN production (B. thermosphacta, L. alimentarius: values ranging from 19.4 to $23.1 \mathrm{mg}-\mathrm{N} 100 \mathrm{~g}^{-1}$ ), moderate production (C. piscicola, Sh. putrefaciens: TVBN ranging from 26.2 to 28.2), and high production (P. phosphoreum, L. sake, L. farciminis, S. liquefaciens and Aeromonas spp.: TVBN ranging from 32.4 to 37.7).

\section{Spoilage potential of the strains}

Correspondence factorial analysis (CFA) for the different spoilage levels indicated the spoilage potential of each bacterial group (Figure 2). This analysis using just the first two principal components allowed all the information to be restored. The first axis itself condensed $80 \%$ of the inertia, serving as a "spoilage axis" separating the non-spoiled and lightly spoiled (NS pole 1 and LS pole2) from the strongly spoiled (SS pole 3). The second axis, representing $20 \%$ of inertia, discriminated between lightly spoiled (LS pole 2) and non-

spoiled (NS pole 1) samples. Projection of individual samples and controls according to planes 1 and 2 of the CFA showed three groups based on spoilage potential (Figure 2). For most species, great variations in spoilage potential were observed within the same species. Some isolates of the same species produced strong spoilage, whereas others had no apparent detrimental effect on sensory quality. Group 1 consisted mainly of samples inoculated with 3 Sh. putrefaciens strains (S1, S2, S5) and 5 controls (T1, T3, T5, T6, T7) that were considered as non-spoiled by the sensory panel. In addition, this group contained one strain of each of the other Gram-negative bacteria (E1, A3, P4) and 2 strains of L. alimentarius (LA2, LA3). Group 2 included the remaining controls (T2, T4, T8) and isolates that spoiled the product 
slightly: 2 strains of each of the Gram-negative species (E2, E4, A1, A2, S3, S4, P1, P5), 4 C. piscicola strains (C1, C3, C4, C5), the 3 remaining strains of L. alimentarius (LA1, LA4, LA5) and one of L. sake and B. thermosphacta (LS2, B1). Group 3 consisted primarily of the 5 L. farciminis strains (LF1, LF2, LF3, LF4, LF5), 4 L. sake (LS1, LS3, LS4, LS5) and 4 B. thermosphacta (B2, B3, B4, B5). Furthermore, this group contained the Gram-negative strains E3, E5, A4, A5, P2, P3. All the isolates tested in this group were strong spoilers, and the samples were rejected by the sensory panel. 
Figure 2. Classification of bacterial strains depending on their spoilage potential according to plane 1-2 of correspondence factorial analysis. Component 1: $80 \%$ of variance; Component 2: $20 \%$ of variance.

NS: non-spoiled; LS: lightly spoiled; SS: strongly spoiled. Strains and control sample labels are defined in table 1.

SIMULTANEOUS REPRESENTATION

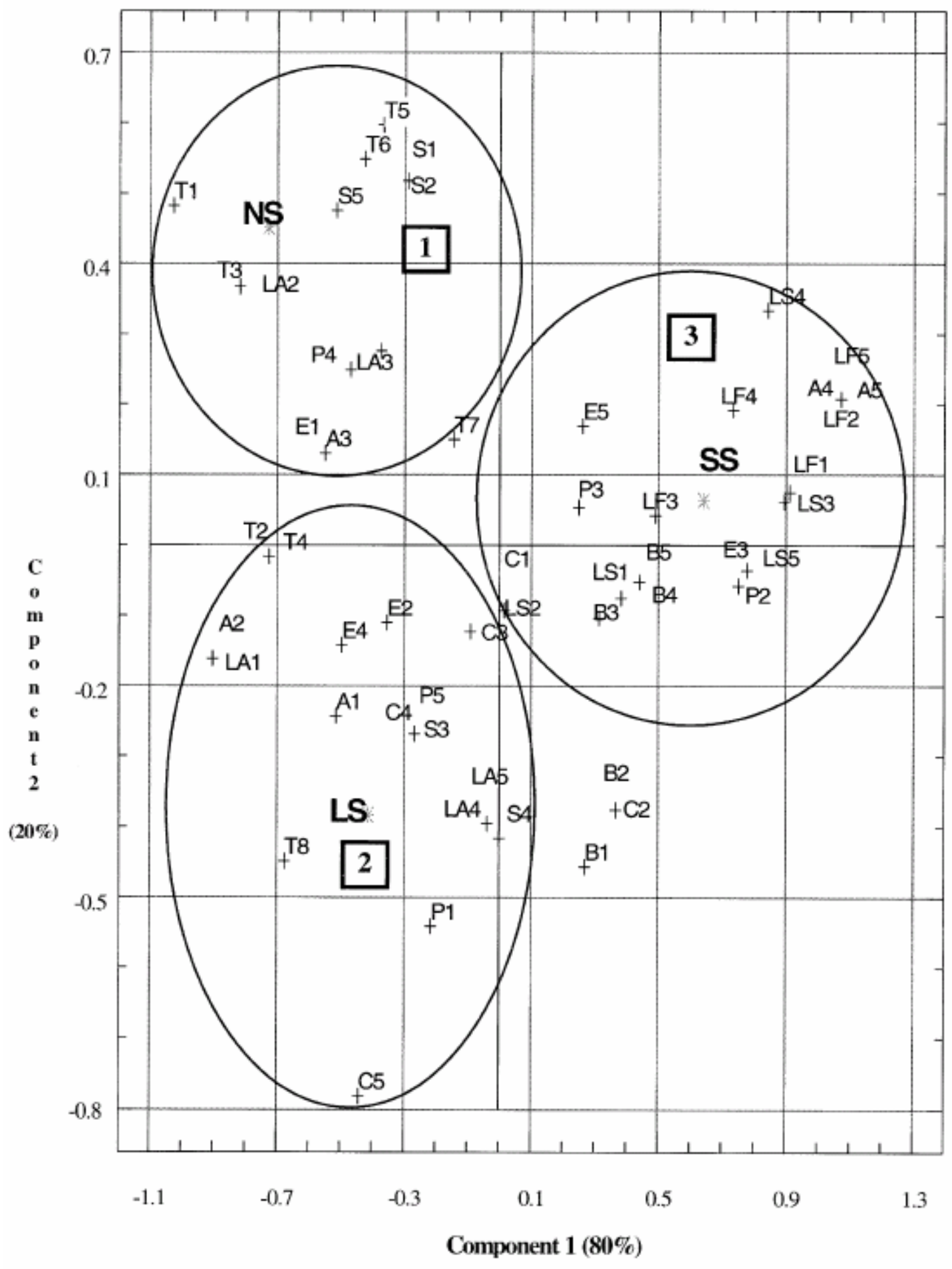




\section{Production of off-odours}

The results of the profiling test were subjected to principal component analysis (PCA). Figures 3A and 3B show respectively the variable plot of sensory descriptors and the sample plot according to plane 1-2 of PCA. Seventy-five percent of the inertia was restored by these axes. The charts indicate that inoculated bacteria produced off-odours. In most cases, specific sensory descriptors could be correlated with a given bacterial species.

Control samples (T1 to T8), clustered together in a central position on PCA plane 1 (Figure 3 B) and could not be associated with any off-odours and were regarded as neutral (Ham/Grass). All L. alimentarius strains and some other isolates differing from sensory group behaviour were adjacent to the control samples. Inoculation of $L$. sake and L. farciminis resulted in marked acidic and sulphurous odours. Butter and plastic odours were commonly associated with $B$. thermosphacta and $C$. piscicola. The latter group also produced some rubbery odours. Two $P$. phosphoreum isolates were characterised by an acidic odour. These results are summarised in Table 4 .

Table 4. Off-odours associated with the different bacterial groups, except for Shewanella putrefaciens and Serratia liquefaciens, for which no specific off-odours were detected.

\section{Bacterial group Sensory characteristics}

Lactobacillus alimentarius

Lactobacillus sake and farciminis

Brochothrix thermosphacta

Aeromonas spp

Carnobacterium piscicola neutral (green/cooked meat aroma)

sulphurous and weakly acidic, except for LS3 (amino) and LF5 (cabbage)

butter/plastic and/or rancid cheesy/sour and neutral (green/cooked meat) butter/plastic, rubbery and neutral (green/cooked meat) 
It was impossible to associate Sh. putrefaciens and S. liquefaciens strains with specific off-odours since each isolate considered individually appeared to be characterised by a particular aroma. For example, S. liquefaciens isolates produced different off-odours such as acidic, rubbery or cheesy, and Sh. putrefaciens strains were characterised by rancid or sulphurous odours.

Figure 3. Correlation between bacterial strains and sensory descriptors according to plane 1-2 of principal component analysis. Component 1: $48 \%$ of variance; Component 2: $27 \%$ of variance.

A: variable plot of sensory descriptors. Codes for sensory descriptors are defined in table 2.

B: sample plot. Strains and control sample labels are defined in table 1.
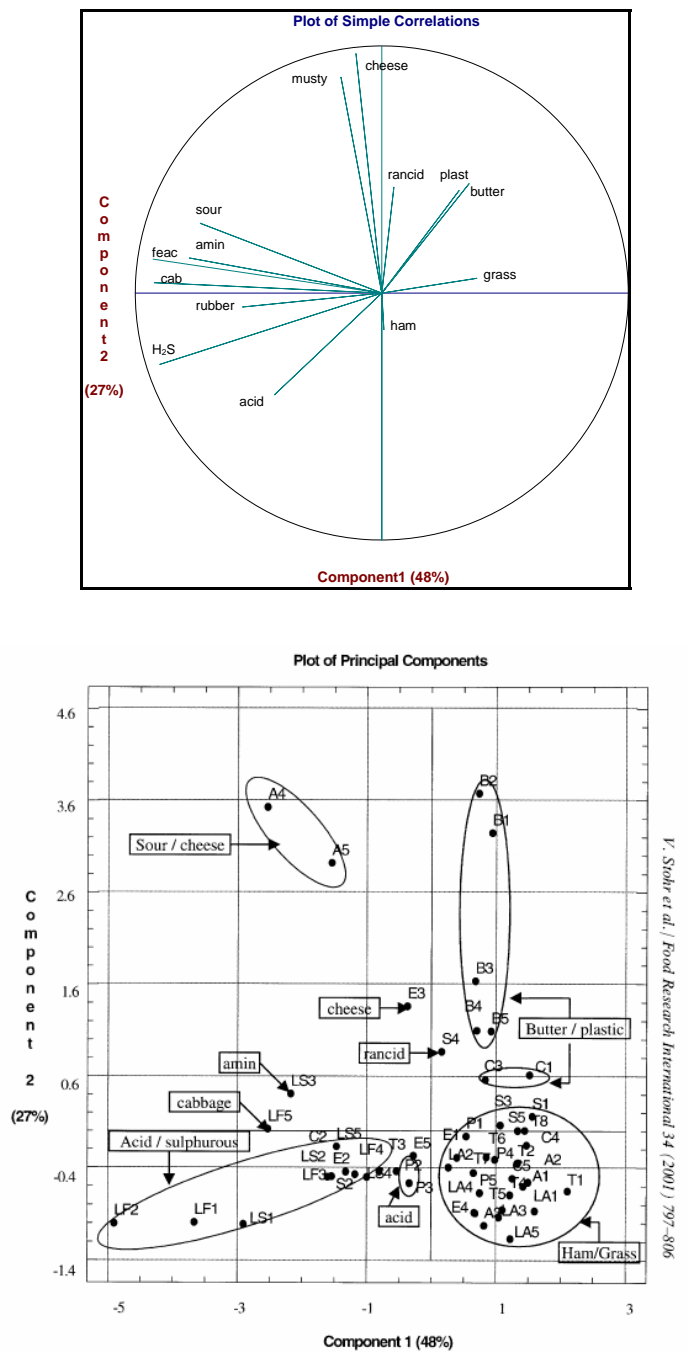


\section{DISCUSSION}

\section{Bacterial growth on cold-smoked salmon}

Most species inoculated into cold-smoked salmon proliferated to high levels $\left(10^{8}-10^{9} \mathrm{cfu} \mathrm{g}^{-}\right.$

${ }^{1}$ ). The prevalence of LAB at a high level was not surprising since many studies have shown that they proliferate readily in cold-smoked salmon (Leroi et al., 1996; Nilsson et al., 1999; Duffes et al., 1999). These facultative anaerobic organisms appear to be well-adapted to vacuum-packaging and more resistant than Gram-negative bacteria to the high salt content found in cold-smoked salmon (Leroi et al., 2000). The count for Sh. putrefaciens remained 1 to $3 \log _{10}\left(\mathrm{cfu} \mathrm{g}^{-1}\right)$ lower than the other counts, depending on the isolate. As Sh. putrefaciens is primarily a respiratory bacterium (Gram \& Huss, 1996), sensitive to different salt levels, depending on the strain (Jørgensen \& Huss, 1989), the salt content of the product and vacuum-packaging were probably responsible for this result. $P$. phosphoreum counts rapidly reached $10^{7}-10^{8}$ cfu g $^{-1}$ after one week of storage and then decreased slightly by 1 log unit. This growth pattern could have been due to the rapid depletion of TMAO in cold-smoked salmon following the growth phase, as shown by Truelstrup Hansen (1995).

\section{Chemical characteristics of inoculated cold-smoked salmon}

In samples inoculated with Gram-negative bacteria, TMA concentrations were similar to those commonly found in spoiled vacuum-packed cold-smoked salmon (Truelstrup Hansen, 1995). TVBN production was high in most samples and sometimes above $35 \mathrm{mg}-\mathrm{N}-100 \mathrm{~g}^{-1}$, the European standard for fresh salmon (Commission of the European Communities, 1995). High TVBN production was generally correlated with high TMA production, except for $L$. sake and L. Farciminis, which were unable to produce TMA but generated high amounts of TVBN, probably due to ammonia resulting from deamination of amino acids. 


\section{Spoilage potential and off-odour production of bacterial strains}

Gram-negative bacteria were generally regarded as less effective spoilage bacteria by the panel, although some strains of the different groups were found to belong to the SS class. These results are quite different from those observed for other fresh or vacuum-packed fish products in which Sh. putrefaciens and $P$. phosphoreum were found to be the main spoilage organisms (Gram et al., 1987; Dalgaard 1995; Gram \& Huss, 1996). As the difference in spoilage behaviour within groups could have been due to group heterogeneity, more tests are needed for accurate identification of the isolates. Other reports have also found that the production of off-odours is strain-dependent (Dalgaard 1995; Leroi et al., 1998). Sh. putrefaciens was unable to spoil the product and did not produce strong off-odours, probably because of the moderate growth of this bacterium on the product. However, this species was one of the highest producers of TMA, which implies that TMA cannot be considered as a good spoilage indicator for cold-smoked salmon. S. liquefaciens was one of the major Gramnegative bacteria responsible for spoilage (most strains belonging to the LS or SS classes) even though no particular off-odours were associated with this species. Truelstrup Hansen \& Huss (1998) reported that $S$. liquefaciens was the main representative species of Enterobacteriaceae isolated from cold-smoked salmon, and this finding was confirmed in our laboratory (unpublished data). The role of $P$. phosphoreum in spoilage was quite similar to that of S. liquefaciens (adjacent positions of the samples on PCA and CFA). No specific sensory descriptor was associated with sensory deterioration for three of the $P$. phosphoreum strains, whereas two isolates were characterised by distinct acidic odours. The production of these types of aromas was previously observed by Truelstrup Hansen (1995), who mentioned in particular the production of acetic acid by a $P$. phosphoreum strain inoculated into salmon juice and cold-smoked salmon blocks. 
The greatest cold-smoked salmon spoilers were found among Gram-positive bacteria. These isolates showed the most homogeneous behaviour for spoilage ratings and sensory descriptors. B. thermosphacta, $L$. sake and $L$. farciminis appeared to be the main organisms involved in spoilage. For B. thermosphacta, the strong off-odours detected were associated with butter/plastic or rancid descriptors. The production of such off-aromas by this bacterial species has already been reported for spoiled fresh red meat (Dainty \& Mackey, 1992). Talon et al. (1994) found that $B$. thermosphacta produced acids during meat spoilage that conferred rancid and cheesy odours on the product. $L$. sake and $L$. farciminis isolates released strong sulphurous and (to a lesser extent) acidic odours. In vacuum-packed meat, Dainty \& Mackey (1992) and Borch et al. (1996) found that LAB production of lactic and acetic acids from sugars was associated with strong acidic odours. Huss et al. (1995) observed the same phenomenon in fresh vacuum-packed cod. Finally, Truelstrup Hansen (1995) showed that LAB isolated from cold-smoked salmon were able to produce acidic and sulphurous odours on salmon blocks and that some strains of $L$. sake produced hydrogen sulphide, which may have accounted for part of the sulphurous odour detected in our study. Among Lactobacillus species, L. alimentarius isolates did not spoil the product. This species produced TVBN in quantities two-fold lower than those of other species, even though acidification was identical. Thus, the acid component was apparently not sufficient to cause sensory rejection of the product by the panel, but volatile amines may have been more directly involved. C. piscicola isolates were not considered as spoilage organisms by the panel, which is in agreement with previous findings that Carnobacteria are not involved in cold-smoked salmon spoilage (Leroi et al., 1996; Paludan-Muller et al., 1998; Duffes et al., 1999).

It is noteworthy that differences in off-odour production have often been observed for smoked salmon extract juice and salmon blocks. For instance, S. putrefaciens produced strong off-odours in juice (Leroi et al., 1998), but did not produce such odours or induce spoilage in 
salmon blocks. Conversely, P. phosphoreum and Lactobacillus spp showed no or weak offodours in juice (Leroi et al.,1998), whereas these organisms released strong off-odours from salmon blocks in the present study and clearly displayed a high spoilage potential. The same features were reported by Truelstrup Hansen (1995), who showed that a given L. sake strain produced no sulphur-like off-odours in salmon juice, but sour and sulphurous off-odours on salmon blocks. As suggested by this author, the lack of natural substrates in the fish juice model could account for the difference in behaviour. Accordingly, it would seem more relevant to assess the spoilage potential of bacterial strains in the sterile smoked salmon model as it is more similar to the commercial product.

\section{CONCLUSION}

This study found that the three Gram-positive bacteria among the nine bacterial groups investigated had strong spoilage potential (B. thermosphacta, L. sake and L. farciminis), whereas two Gram-negative species (S. liquefaciens and $P$. phosphoreum) were characterised as weak or strong spoilers, depending on the strain. These results may account for the lack of consensus in the literature between the total counts classically enumerated on cold-smoked salmon (total viable and total LAB counts) and the observed sensory characteristics. Moreover, no single physico-chemical indicator was associated with microbial quality and sensory spoilage, since the bacteria involved in spoilage showed different patterns for $\mathrm{pH}$ and TMA and TVBN production. This study was performed in pure culture conditions, but further investigations are needed to determine the incidence of the bacteria in mixed cultures. Competition between species may change the overall metabolism, and associations of volatile compounds may modify the perception of off-odours. 


\section{ACKNOWLEDGEMENTS}

This study was carried out as part of an EU-FAIR project. The authors are grateful to F.

Chevalier, L. Campello and J. Cornet for skilled technical assistance and to E.M. Qannari (ENITIAA) for advice concerning statistical calculations.

\section{REFERENCES}

Borch, E., Kant-Muermans, M-L., \& Blixt, Y. (1996). Bacterial spoilage of meat and cured meat products. Int. J. Food Microbiol., 33, 103-120.

Civera, T., Rarisi, E., Amerio, G.P., \& Giaccone, V. (1995). Shelf-life of vacuum-packed smoked salmon; microbiological and chemical changes during storage. Arch. Lebensmittelhyg., 46, 13-17.

Commission decision of 8 March 1995 fixing the TVB-N (total volatile basic nitrogen) limit values for certain categories of fishery products and specifying the analysis methods to be used. Commission of the European Communities C (95) 362 final, Brussels, 8 March 1995.

Conway, E.J., \& Byrne, A. (1933). An absorption apparatus for the micro-determination of certain volatile substances. Biochem. J., 27, 419-429. 
Dainty, R.H., \& Mackey, B.M. (1992). The relationship between the phenotypic properties of bacteria from chill-stored meat and spoilage processes. J. Appl. Bacteriol., Symposium Suppl. 73, 103S-114S.

Dalgaard, P. (1995). Qualitative and quantitative characterization of spoilage bacteria from packed fish. Int. J. Food Microbiol., 26, 319-333.

Dalgaard, P., Gram, L., \& Huss, H.H. (1993). Spoilage and shelf-life of cod fillets packed in vacuum or modified atmospheres. Int. J. Food Microbiol., 19, 283-294.

Duffes, F., Corre, C., Leroi, F., Dousset, X., \& Boyaval, P. (1999). Inhibition of Listeria monocytogenes by in situ-produced and semi-purified bacteriocins of Carnobacterium spp. on vacuum-packed cold-smoked salmon stored at $4^{\circ} \mathrm{C}$ and $8^{\circ} \mathrm{C}$. J. Food Protect., 62 (12), 1394-1403.

Gram, L., \& Huss, H.H. (1996). Microbiological spoilage of fish and fish products. In: M. Jakobsen (editor), Symposium of Microbial Food Spoilage, October 15-16th, Technical University of Lingby, Denmark. Int. J. Food Microbiol., 33, 121-137.

Gram, L., Trolle, G., \& Huss, H.H. (1987). Detection of specific spoilage bacteria from fish stored at low $\left(0^{\circ} \mathrm{C}\right)$ and high $\left(20^{\circ} \mathrm{C}\right)$ temperatures. Int. J. Food Microbiol., 4, 65-72.

Huss, H.H., Jeppesen, V.F., Johansen, C., \& Gram, L. (1995). Biopreservation of fish products; A review of recent approaches and results. J. Aquatic Food Product Technol.,4 (2), 5-26. 
Joffraud, J.J., Leroi, F., Roy, C., \& Berdagué J.L. Characterisation of volatile compounds produced by bacteria isolated from the spoilage flora of cold-smoked salmon. Int. J. Food Microbiol., in press.

Joffraud, J.J., Leroi, F., \& Chevalier, F. (1998). Development of a sterile cold-smoked fish model. J. Appl. Microbiol., 85, 991-998.

Jørgensen, B.R., \& Huss, H.H. (1989). Growth and activity of Shewanella putrefaciens isolated from spoiling fish. Int. J. Food Microbiol., 9, 51-62.

Kunert, J., \& Qannari, E.M. (1999). A simple alternative to generalized procrustes analysis: application to sensory profiling data. Journal of Sensory Studies, 14, 197-208.

Leroi, F., Arbey, N., Joffraud, J.J., \& Chevalier, F. (1996). Effect of inoculation with lactic acid bacteria on extending the shelf life of vacuum-packed cold-smoked salmon. Int. J. Food. Sci. Technol., 31, 497-504.

Leroi, F., Joffraud, J.J., Chevalier, F., \& Cardinal, M. (1998). Study of the microbial ecology of cold-smoked salmon during storage at $8^{\circ} \mathrm{C}$. Int. J. Food Microbiol., 39, 111-121.

Leroi, F., Joffraud, J.J., \& Chevalier, F. (2000). Effect of salt and smoke on the microbiological quality of cold-smoked salmon during storage at $5^{\circ} \mathrm{C}$ as estimated by the factorial design method. J. Food Protect., 63 (4), 502-508. 
Lyhs, U., Björkroth, J., Hyytiä, E., \& Korkeala, H. (1998). The spoilage flora of vacuumpackaged, sodium nitrite or potassium nitrate treated, cold-smoked rainbow trout stored at $4^{\circ} \mathrm{C}$ or $8^{\circ} \mathrm{C}$. Int. J. Food Microbiol., 45, 135-142.

NF V 45-065 (1997). Poissons transformés. Saumon fumé. Association Française de Normalisation (AFNOR), Paris.

Nilsson, L., Huss, H.H., \& Gram, L. (1999). Growth control of Listeria monocytogenes on cold-smoked salmon using a competitive lactic acid bacteria flora. J. Food Protect., 62, 336-342.

Paludan-Müller, C., Dalgaard, P., Huss, H.H., \& Gram, L. (1998). Evaluation of the role of Carnobacterium piscicola in spoilage of vacuum- and modified-atmosphere-packed cold-smoked salmon stored at 5². Int. J. Food Microbiol., 39, 155-166.

Talon, R., Montel, M.C., Labadie, J.C., Larpent, J.P., \& Fournaud, J. (1994). Altération des viandes par les bactéries lactiques. In Bactéries Lactiques: Aspects fondamentaux et technologiques, ( ${ }^{\text {nd }}$ vol.) (pp.573-580). Uriage: Lorica.

Truelstrup Hansen, L. (1995). Quality of chilled, vacuum packed cold-smoked salmon - Ph.D. thesis. Royal Veterinary and Agricultural University, Frederiksberg, Denmark.

Truelstrup Hansen, L., Gill, T., Drewes Røntved, S., \& Huss, H.H. (1996). Importance of autolysis and microbiological activity on quality of cold-smoked salmon. Food Res. Int., 29 (2), 181-188. 
Truelstrup Hansen, L., Drewes Røntved, S., \& Huss, H.H. (1998). Microbiological quality and shelf-life of cold-smoked salmon from three different processing plants. Food Microbiol., 15, 137-150.

Truelstrup Hansen, L., \& Huss, H.H. (1998). Comparison of the microflora isolated from spoiled cold-smoked salmon from three smokehouses. Food Res. Int., 31 (10), 703711.

Van Spreekens, KJA. (1974). The suitability of a modification of Long and Hammer's medium for the enumeration of more fastidious bacteria from fresh fisheries products Arch. Lebensmittelhyg., 25, 213-219. 